\title{
Clinton plans offer hints of technology agenda
}

Washington. Ever since his election victory earlier this month, US President-elect Bill Clinton has uttered hardly a word about future policies, including those involving science and technology. However, this silence has not dampened speculation that Clinton's enthusiasm for federal research and development is more likely to pay off for technology and applied research than it is for basic science.

One clue to Clinton's thinking are the criteria for selecting the president's science House Office of Science and Technology Policy. Clinton is looking for someone with ing in the academic community, according to an aide to Senator Al Gore, the Vice President-elect. The aide, who has already collected the names of more than a hundred possible candidates for the position, offers as an example the résumé of chemist Mary Good, vice-president for technology at Allied-Signal Inc. and a former chair of the board that oversees the National Science Foundation. Good may not be offered the job, but it is clear that her background is preferable to that of physicist D. Allan has spent most of his career at Yale University and has never worked in industry.

What this means for Clinton's policies towards research depends on the authority given to the science adviser, of course. Traditionally, the science advisor has been relegated to coordinating federal research adviser, who doubles as director of the White strong industrial experience and high standBromley, the current science adviser who

policy after the fact or, worse, writing reports and convening committees to give the appearance of such a policy where none exists. But the presence of Gore, arguably the most science-literate politician ever to reach the White House, bodes well. Clinton has designated Gore as his technology tsar, using research to strengthen US industry in the same way that Dan Quayle, the outgoing vice president, tried to use regulatory reform. Although the new science adviser may report directly to Gore rather than to Clinton, a mandate from the White House is seen as preferable to Bromley's ostensible access to the president.

Another telling indicator is the composition of Clinton's economic transition team. Voters elected Clinton because of their concern about the economy, and he sees a strong research base as essential for an industrial recovery. His choice of Robert Reich, a Harvard University economist and advocate of industrial policy to lead the economic transition team reflects this agenda. In turn, Reich has selected Laura D'Andrea Tyson, an economist at the University of California, Berkeley, and another proponent of industrial policy, to guide a team looking at technology and manufacturing policy.

Their mission is to translate Clinton's promises into concrete policies for the new administration. This includes helping to select people for important positions, providing details of how Clinton would increase domestic research spending to at least match military spending and tilt government-

\section{EMF report draws fire}

Washington. When the health effects of electric and magnetic fields (EMF) are studied, the only predictable conclusion is that the results will be controversial. In 1989, the US Environmental Protection Agency (EPA) started a furore when it released a report suggesting that EMF radiation might be linked to leukaemia and other cancers. Now, three years later, the other side has spoken.

A scientific panel commissioned by the Committee on Interagency Radiation Research and Policy Coordination, made up of representatives of several federal agencies, concluded in a report* released last week that EMF "does not appear to constitute a public health problem" and that research on the subject should not receive more funding. But the ink was not even dry before the report was criticized by those who consider EMF radiation to be a significant health hazard.

Critics suggest that the 11-member panel, which reviewed about 1,000 published studies, was assembled primarily to rebut the
EPA report. They point out that one of the authors, Dimitrios Trichopoulos, a Harvard University epidemiologist, has testified on any link between EMF and public health. (An official from Oak Ridge Associated Universities, which prepared the report, says that she was aware of Trichopoulos's role but did not feel that it presented a problem.)

Others point out that the report's executive summary, which recommends against a major expansion of a national EMF research programme, seems to run counter to its individual chapters, which urge dozens of new studies. In a letter to the panel sent on 30 October, William Farland, director of health and environmental assessment at EPA, asked that the panel make clear that the report does not reflect the views of the agencies that paid for it.

Christopher Anderson

* Heaith Effects of Low-Frequency Electric and Mag netic Fields, Oak Ridge Associated Universities, 1992 (US Government Printing Office, publication no. 029 000-00443-9). behalf of electric utility companies against sponsored research towards industrial needs. Tyson, a coauthor of a report entitled Linking Trade and Technology Policies released earlier this year by the US National Academy of Engineering, believes that government can help US industry compete without erecting trade barriers.

Finally, there are the opinions of Clinton's campaign advisers, whose stature ranges from having provided one-on-one briefings to having simply sent a letter to the candidate. One genuine inside player is the Council on Competitiveness, a private thinktank set up by John Young, the former head of Hewlett-Packard and a prominent supporter during the campaign. Last week, at a seminar on science policy under the new administration sponsored by the American Association for the Advancement of Science, the executive vice president of the council, Daniel Burton, predicted that the Clinton presidency would include:

- Greater effort to involve the private sector in setting US priorities for research and development;

More government centres, perhaps under the auspices of the National Institute of Standards and Technology, for collaborative research with industry and to commercialize government-funded technology;

- More investment in "technology infrastructure", a term that is somewhat undefined but is believed to include highperformance computing and networks;

- A greater focus on manufacturing processes. During the campaign, Clinton promised to create 170 manufacturing extension centres that would do for high-technology industries what agricultural extension centres have done for farming;

- A broader interest in global science, both to collect information and to harmonize policies. As Burton put it, "we have 50,000 troops in Japan and only five commercial officers. Something about that balance is wrong."

Much of this policy is expected be delegated to the Department of Commerce, which has had a Technology Administration since 1989. Although the programme has been nearly invisible during the Bush administration, Clinton is said to favour giving it sufficient authority and money to carry out its mandate.

Basic research is not expected to be at the centre of whatever technology policies Clinton adopts. Yet his willingness to create new applied research programmes suggests that he does not intend to cannibalize basic research to promote his technology plans. After the concerns raised about the direction in which the National Science Foundation and the National Institutes of Health appear headed (see page 285), that may be welcome news to bench scientists.

Christopher Anderson 